Article

\title{
Technocratic Populism in Italy after Berlusconi: The Trendsetter and his Disciples
}

\author{
Antonino Castaldo ${ }^{1}$ and Luca Verzichelli ${ }^{2, *}$ \\ ${ }^{1}$ Instituto de Ciências Sociais, University of Lisbon, 1600-189 Lisbon, Portugal; E-Mail: antonino.castaldo@gmail.com \\ 2 CIRCaP-Department of Social, Political and Cognitive Sciences, University of Siena, 53100 Siena, Italy; \\ E-Mail: luca.verzichelli@unisi.it \\ * Corresponding author
}

Submitted: 14 June 2020 | Accepted: 3 September 2020 | Published: 17 December 2020

\begin{abstract}
Notwithstanding the speculations from the literature, the empirical analyses still neglect the convergence between populism and technocracy. The Italian case can be of some interest in this perspective, given the rise of technocratic populism since Silvio Berlusconi's rise to power in 1994. By analyzing the style of leadership and the processes of ministerial appointment and delegation, we argue that Berlusconi has been a trendsetter, more than a coherent example of technocratic populist leader. On the one hand, he played the role of the entrepreneur in politics, promising to run the state as a firm. Moreover, he adopted an anti-establishment appeal, delegitimizing political opponents and stressing the divide between 'us' (hardworking ordinary people) and 'them' (incompetent politicians). On the other hand, however, his anti-elite approach was mainly directed towards the 'post-communist elite.' Extending the analysis to the following two decades, we introduce a diachronic comparison involving three examples of leadership somehow influenced by Berlusconi. Mario Monti represents the paradox of the impossible hero: A pure technocrat unable to take a genuinely populist semblance. Matteo Renzi represents the attempt to mix a populist party leadership with a technocratic chief executive style. Finally, Salvini represents the pure nativist heir of Berlusconi, as the new leader of the right-wing camp. The latest developments of executive leadership in Italy, and the re-emergence of other residual hints of technocratic populism, will be discussed in the final section of the article, also in the light of the evident impact of the 2020 pandemic outbreak on the practices of government.
\end{abstract}

\section{Keywords}

Berlusconi; Conte; Italy; leadership; Monti; populism; Renzi; Salvini; technocratic populism

\section{Issue}

This article is part of the issue "Varieties of Technocratic Populism around the World" edited by Petra Guasti (Institute of Sociology of the Czech Academy of Sciences, Czech Republic) and Lenka Buštíková (Institute of Sociology of the Czech Academy of Sciences, Czech Republic / Arizona State University, USA).

(C) 2020 by the authors; licensee Cogitatio (Lisbon, Portugal). This article is licensed under a Creative Commons Attribution 4.0 International License (CC BY).

\section{Introduction}

Italian politics have recently offered a fascinating scenario to assess the concept of 'technocratic populism' empirically. This notion refers to a 'thin' ideology that rejects the traditional left-right dimension and promises apolitical expert solutions safeguarding the 'ordinary people' (Buštíková \& Guasti, 2019, p. 304). Several authors have placed the roots of a prototypical wealthy techno-pop and businessman approach to political lead- ership in the crisis of the mid-1990s when the model of party-government democracy known as the 'first Italian republic' was dissolved. 25 years later, the nature of the new model of parliamentary democracy is still under discussion. However, we know that the figure of Silvio Berlusconi was crucial to explain that transition and some of the following political changes.

This thematic issue allows us to evaluate the novelty emerged with the leadership of Berlusconi, and the similarities in the styles of leadership occurred more 
recently on the Italian political scene. In this article, we discuss the multidimensional nature of technocratic populism, contending that some of its elements have been relevant during Berlusconi's rise to power. Mixing some prototypical elements of populism with the legitimacy of his professional expertise, he imposed a novel form of leadership, which would have somehow inspired other protagonists. However, such combined rhetoric (unmediated political communication, business expertise, decreasing party organizational influence, direct legitimation of governmental leadership) has met several obstacles in the long run. Already during the consolidation of Berlusconi's leadership, some evident deviations from the technocratic populism model emerged. Other elements of variation from the model arose during the 2010s, when several political leaders tried to take the baton of Berlusconi original style. However, they moved towards different types of leadership.

After a brief conceptual overview and a short presentation of the origins of Italian technocratic populism, we summarize the main elements of Berlusconi's approach as an adaptive and pragmatic leader, able to play the role of technocratic populism' trendsetter' but also to significantly deviate from his original model during his staying-in-power. This account is complemented by looking to other influential leaderships-Mario Monti, Matteo Renzi, and Matteo Salvini-selected on the bases of 'most dissimilar' career characteristics. This comparative analysis brings us to evaluate the controversial legacy of technocratic populism in Italy. The formation of the Conte II government (2019) and the peculiar situation of the limitation of parliamentary democracy during the Covid-19 crisis (2020) affect the irregular trend of populist leadership in Italy once again. However, a few latent and persisting elements of the model still may be found, which let us think that the era of technocratic populism may not be closed.

\section{Populism, Technocracy and Technocratic Populism}

In recent years, populism has become a hot topic in the academic debate. Consequently, the scientific literature on this phenomenon has expanded exponentially (e.g., Barr, 2009; Castaldo, 2018; Eatwell \& Goodwin, 2018; Hawkins, Carlin, Littvay, \& Rovira Kaltwasser, 2019; Moffitt, 2016; Pappas, 2019; Rovira Kaltwasser, Taggart, Ochoa Espejo, \& Ostiguy, 2017; Zulianello, 2020). The intense academic debate has led to several interpretations of such a 'slippery concept.' Firstly, populism has been conceived as a thin and adaptable ideology that sees society as characterized by the divide between the 'pure people' and the 'corrupted elite' (Mudde, 2004). Secondly, populism has been interpreted as a rhetoric that takes advantage of diffuse public sentiments of anxiety, pushing the ordinary people to challenge the political establishment (Abt \& Rummens, 2007). Thirdly, several contributions focused on populism as a type of organization, characterized by the presence of (new kind of) charismatic leaders (Taggart, 2000). Finally, populism has been seen as a style of communication that bypasses intermediaries and establishes a direct connection between the leader and the people (Jagers \& Walgrave, 2007).

Despite such a variety of interpretations, the critical element at the core of all these definitions is the focus on 'the people.' Populism is based on the idea that the political establishment ignores the aspirations of the people and that a charismatic leader is able to connect directly with the people and to speak on its behalf (Caiani, 2019). Obviously, the definition of this crucial element appears to be ambiguous when used by different populists, and various studies try to clarify who 'the people' actually are. Canovan (1984) identifies three possible populist rhetorical interpretations of the people: 1) A nativist version where the 'us' is the 'nation' and the 'them' are migrants and ethnic/religious minorities; 2) the people intended in economic terms, as the 'underdog,' which is characterized by an intense hostility to economic differences; and 3) a focus on the 'ordinary people' and a nostalgic desire for a simpler life.

Other classifications distinguish between 'exclusionary' radical-right populism and 'inclusionary' radical-left populism (Abt \& Rummens, 2007; Mudde \& Rovira Kaltwasser, 2013). This distinction recalls, respectively, the first two types identified by Canovan. A third category, so far identified as 'mainstream populism' (e.g., Tony Blair; see Mair, 2002) or 'center-right populism' (e.g., Silvio Berlusconi; see Pasquino, 2007), is also relevant. This kind of populism, somehow related to Canovan's third type, is less polarizing than the inclusionary and exclusionary model, focusing on moderate and governmental actors. Technocratic populism can be located in this third category (Buštíková \& Guasti, 2019).

Following the definition of technocratic populism provided above, we highlight the core dimensions of this new form of populism: A 'thin' anti-elite ideology that emerges in critical junctures, rejecting the traditional left-right divide and delegitimizing political opponents. The legitimation strategy includes the promise to run the state as a firm, offering expertise to solve the problems of ordinary people. Once in power, technocratic populism's survival strategy is based mainly on two pillars: Attempts to instill civic apathy and discourage mobilization thanks to the formal adoption of a 'technocratic' approach to governance; adoption of short-term policies that allows them to keep voter support, and a combination of redistributive and pro-market policies (Buštíková \& Guasti, 2019; Havlík, 2019).

Given this conceptualization, technocratic populism represents a strong critique of the crucial institutions and practices of representative democracy. Indeed, both the constituting elements of technocratic populism emerged recently as two of the most relevant arguments to dispute the party government model of representative democracy (Caramani, 2017). Despite the antagonism between the primary goal of populism- 
restoring people's power-and the technocratic goal of empowering experts (Bickerton \& Accetti, 2017), these two elements also share a few features. Both of them picture themselves as anti-politics, sharing a minimalist/Schumpeterian interpretation of democracy and claiming that the left-right dimension should not matter anymore. Hence, the real enemy of technocratic populism is the party government model. Due to their nonpluralistic conception of society, promoters of technocratic populism shared the idea of a united general interest and the will to establish a relationship between the people and the elite, which is not mediated by political parties or other kinds of intermediary institutions (Bickerton \& Accetti, 2017; Caramani, 2017).

In this general frame, the present article will try to answer two questions: At first, what about the endurance of Berlusconi's original technocratic populism model? Secondly, what are the legacies of such a model? The first question will be approached looking to the diachronic evolution of Berlusconi's leadership, while the second one may be explored by comparing the experiences of some of the most influencial Italian leaders of the past two decades.

More in detail, we will start from the analysis of the long-term evolution of a trendsetter technocratic populism leader who was able to stand as the most durable candidate premier between 1994 and 2013 (Table 1). At the beginning of such a period, Berlusconi represented an innovative leadership, challenging two figures connected to the previous party government model: the ex-communist Occhetto and the ex-Christian Democrat Segni. Later, Berlusconi won the 2001 and 2008 elections while he was defeated two times (1996 and 2006) by the centre-left coalition led by Romano Prodi, a reputed former technocrat and policy expert who expressed a weak leadership since he was never able to build his personal party. To find other leaders assimilable to the technocratic populism model, Italians had to wait until 2013, when the technocratic prime minister Mario Monti decided to run the political competition, leading a centrist cartel (and a personal party at the core of such a coalition).
Monti ranked only fourth in a complicated electoral contest, where nobody won. Indeed, all the leaders standing for the prime ministerial post renounced, and the political game expressed, during the following legislative term, three governmental leaders from the Democratic Party.

Among these three, we selected Matteo Renzi, who cumulated the positions of party secretary and prime minister (2014-2016), reaching high peaks of popularity, but proposing himself as a highly divisive leader. Renzi's resignation opened another political season that culminated in the 2018 elections. During such a period, another significant leadership has been that of Matteo Salvini, who became the leader of the centre-right coalition and probably the most popular personality during the short period of the Conte I government (2018-2019). In this cabinet, Salvini served as vice-prime minister and minister of interior. In sum, Monti (the prime minister who succeeded the trendsetter, as a potential technocratic populist political leader), Renzi (the main political opponent of the latest Berlusconi, often associated to him in terms of style and assertiveness) and Salvini (Berlusconi's successor as a leader of the conservative camp) constitute three dissimilar cases of personalities who may have inherited some (but only some) traits of the technocratic populism model. In the concluding section, we also focus on the personality of Giuseppe Conte, a secondary character of the Five Star Movement (5SM) who showed a relevant political talent, surviving to the breakdown of the populist alliance with Salvini to offer himself as the quasi-technocratic leader of a new coalition with the Democratic party. The emergence of the pandemic outbreak allowed Conte to build a new variant of prime ministerial style, which we will discuss in the frame of the technocratic populism model.

\section{From the Sunset of 'Partitocrazia' to the Rise of Technocratic Populism (1983-1994)}

Several studies have supported the interpretation of the Italian First Republic as a paradigmatic example of strong party-government. However, doubts have been raised

Table 1. Competition for prime ministerial leadership in Italy (1994-2020).

\begin{tabular}{|c|c|c|c|c|c|c|c|}
\hline & 1994-1996 & 1996-2001 & 2001-2006 & 2006-2008 & 2008-2013 & 2013-2018 & $2018-2020$ \\
\hline $\begin{array}{l}\text { Electoral } \\
\text { legitimacy }\end{array}$ & Berlusconi (CR) & Prodi $(\mathrm{CL})$ & Berlusconi (CR) & Prodi $(C L)$ & Berlusconi (CR) & & \\
\hline Challengers & $\begin{array}{l}\text { Occhetto (L) } \\
\text { Segni (C) }\end{array}$ & Berlusconi (CR) & Rutelli (CL) & Berlusconi (CR) & Veltroni (CL) & $\begin{array}{l}\text { Bersani (CL) } \\
\text { Monti (C) } \\
\text { Berlusconi (CR) } \\
\text { ??? (5SM) }\end{array}$ & $\begin{array}{l}\text { Salvini (CR) } \\
\text { Renzi (CL) } \\
\text { Di Maio (5SM) }\end{array}$ \\
\hline $\begin{array}{l}\text { Stand-in } \\
\text { leader }\end{array}$ & Dini (Tech) & $\begin{array}{l}\text { D'Alema }(\mathrm{CL}) \\
\text { Amato }(\mathrm{CL})\end{array}$ & & & Monti (Tech) & Letta (CL) & $\begin{array}{l}\text { Conte (FSM/Tech) } \\
\text { Renzi (CL) } \\
\text { Gentiloni (CL) }\end{array}$ \\
\hline
\end{tabular}

Note: $\mathrm{L}=$ left; $\mathrm{R}=$ right; $\mathrm{C}=$ centre; Tech = technocrat. 
about the extension of 'partyness of government' (Katz, 1987), analyzing the overall process of policy-making (Cotta \& Verzichelli, 1996). An unusual element of technocratic presence during that political age consisted of the recruitment of a few 'non-partisan ministers' who helped the Italian coalition governments to overcome policy disagreements and transaction costs (Verzichelli \& Cotta, 2018). However, technocratic ministers never constituted an autonomous actor until the 1980s, when the reputation of the traditional governing parties started to vanish. The most significant technocratic 'voice' during that period was that of Guido Carli, former governor of the Italian central bank, who served twice as minister of treasury. Carli and other technocratic personalities pushed the Italian government to support the Delors Plan and the Maastricht Treaty as an act of loyalty to the traditional Italian pro-Europeanism, despite this treaty would have imposed severe retrenchment policies.

Personalities of Europeanist experts (officers of Bankitalia, state managers, and academics) constituted the 'technocratic face' in the Italian debate at the end of the age of 'partitocrazia,' representing a growing segment of the 'ministerial elite' (Verzichelli \& Cotta, 2018). Since the mid-1990s, Italy experienced three non-partisan and technocratic prime ministers (Carlo Azelio Ciampi in 1993, Lamberto Dini in 1995, and Mario Monti in 2011) and a relevant number of unelected and non-aligned ministers, vice-ministers and junior ministers in all the executives alternating in power (Table 2).

Another relevant change during that period of crisis was the resurgence of evident hints of populist mentality. The anti-party sentiments already present at the times of the affirmation of the Common Man's Front in 1946 (Corduwener, 2017; Tarchi, 2015) were nurturing the growing consensus to local civic lists and regionalist movements that elected a few MPs in the late 1980s. Among them, Umberto Bossi, the leader of Lombard autonomists, who merged the small regionalist parties from the wealthy Italian Northern area into a single movement. Although present only in a few regions, the Northern League reached the astonishing result of $8 \%$ of the vote (nationwide) in the 1992 elections.

In its early days as a parliamentary actor, the Northern League supported another fundamental symbol of populism: The idea that judiciary power should be elevated as the emblematic force of people's morality against the madness of politicians. Indeed, mistrust of parties and politicians led to the rise of other populist figures, as the former Tangentopoli prosecutor and champion of justicialism, Antonio Di Pietro. However, nobody had been able to mix technocracy and populism in the Italian debate until the famous TV announcement of the direct engagement in politics of Silvio Berlusconi (25 January 1994).

\section{Berlusconi as a Trendsetter of Italian Technocratic Populism}

In Berlusconi's rhetoric, the praise of technocracy was immediately evident, taking a fundamental role during the phase of his rise to power. The man who had gained popularity as an entrepreneur, business, and media innovator was now offering his service to the whole people. This idea of a skill-based political leadership came together with purely populistic references: the superiority of an Italian way of living and the importance of self-made men. As Marco Tarchi argues (2015, p. 278), this mild variance of populism was much more successful than oth-

Table 2. Technocratic and non-elected members of the government in Italy (1994-2020).

\begin{tabular}{|c|c|c|c|c|c|c|}
\hline & \multicolumn{3}{|c|}{ Entire Government } & \multicolumn{3}{|c|}{ Cabinet ministers } \\
\hline & \multicolumn{3}{|c|}{ \% No parliamentary } & \multicolumn{3}{|c|}{ \% No parliamentary } \\
\hline & $\%$ Non-partisan & experience & $\mathrm{N}$ & $\%$ Non-partisan & experience & $\mathrm{N}$ \\
\hline Berlusconi I (1994) & 3.1 & 6.3 & 64 & 7.7 & 11.5 & 26 \\
\hline Dini (1995) & 96.3 & 94.4 & 54 & 95.0 & 90.0 & 20 \\
\hline Prodi I (1996) & 10.1 & 17.4 & 69 & 14.3 & 19.0 & 21 \\
\hline D’Alema I (1998) & 6.0 & 15.5 & 84 & 3.7 & 25.9 & 27 \\
\hline D’Alema I (1999) & 3.0 & 11.1 & 99 & 0 & 15.4 & 26 \\
\hline Amato II (2000) & 4.9 & 5.0 & 81 & 7.7 & 19.2 & 26 \\
\hline Berlusconi II (2001) & 4.8 & 10.7 & 84 & 8.0 & 20.0 & 25 \\
\hline Berlusconi III (2005) & 2.0 & 10.9 & 101 & 3.8 & 15.4 & 26 \\
\hline Prodi II (2006) & 7.7 & 26.9 & 104 & 3.8 & 11.5 & 26 \\
\hline Berlusconi IV (2008) & 1.6 & 9.8 & 61 & 0 & 4.5 & 22 \\
\hline Monti (2011) & 94.0 & 96.0 & 50 & 100 & 100 & 20 \\
\hline Letta (2013) & 15.4 & 33.8 & 65 & 13.6 & 31.8 & 22 \\
\hline Renzi (2014) & 8.1 & 27.4 & 62 & 11.8 & 35.3 & 17 \\
\hline Gentiloni (2016) & 4.9 & 19.7 & 61 & 5.3 & 31.6 & 19 \\
\hline Conte I (2018) & 9.2 & 22.7 & 66 & 21.1 & 40 & 20 \\
\hline Conte II (2019) & 1.6 & 19.0 & 63 & 4.5 & 27.3 & 22 \\
\hline
\end{tabular}

Source: CIRCaP (n.d.). 
er popular figures of that time, as the aforementioned Di Pietro.

Since the fortune of technocratic populism in Italy is inextricably linked to the political trajectory of Berlusconi, we can apply this framework to better explain the relevance of this leader in shaping the different narratives that have crossed the Italian politics. Accordingly, we distinguish the phase of the rise-topower, when Berlusconi came closer to a pure definition of technocratic populism, from his staying-in-power when he significantly deviated from the model.

In terms of genesis and favorable circumstances for technocratic populism, the Italian case confirms the role of critical junctures. The 1992-1994 period represented fertile ground for such a new narrative. Berlusconi emerged when a deep political crisis generated by corruption and economic recessions had wiped out the old party system. The consequent widespread popular distrust represented a perfect climate for an anti-political message (Tarchi, 2008), focused on the juxtaposition of the inefficient (and corrupted) elite and the image of social fixer and representative of (hardworking) people that Berlusconi offered to his voters (Ruzza \& Fella, 2011). Ideas like the 'liberal revolution' and the 'new Italian miracle' constituted the promise of social changes not promoted by "just another party or faction born to divide, but from a positive force which comes now to unify" (Berlusconi, 2000, authors' translation; Foot, 2014). Although the very first act of 'taking the field' was an explicit invitation to prevent the victory of the left (the communists, according to Berlusconi), the traditional left-right cleavage was somehow abandoned and substituted by a vertical one, opposing the corrupted 'ruling class' to the ordinary people (Zaslove, 2008). However, Berlusconi was soon able to occupy the whole centerright camp renovating the old anti-communist argument used in the late 1940s by the Christian Democracy, which gave new significance to the left-right cleavage. Indeed, Berlusconi demonized former Communists (or more generally the 'leftists') as 'enemies' unworthy of either governmental responsibilities or political respect. Left leaders were presented as recycled politicians from the postwar politics and as representatives of an out of touch leftliberal and metropolitan caste (Fella \& Ruzza, 2013).

The promise to run the state as a firm is another crucial technocratic populism element touched by Berlusconi's narrative. Presenting himself as a 'man of providence' and projecting the image of a successful selfmade entrepreneur (Orsina, 2013), Berlusconi instilled in the electorate the idea that he would be as successful in running the state as he had been in building his economic empire. He stressed his purpose to use the typical private-sector managerial skills to improve the efficiency of the state (Bickerton \& Accetti, 2014). This approach was also evident in the innovative procedures he introduced in the process of party building and in promoting political mobilization campaigns. The business-party example of Forza Italia ('Go Italy!'; Paolucci, 2008) was initially shaped with the help of several pollsters and promoters. The members of the early ruling class of Forza Italia were all personalities from the entourage of the tycoon: managers of the family holding Publitalia, longtime members of the editorial teams of his TV networks and newspaper, and lawyers and consultants close to him and his family. The process of parliamentary recruitment was run by candidature casting and other marketing techniques (Verzichelli, 1998).

As said, Berlusconi organized his campaigns around the figure of the entrepreneur as a self-made man. The clear message from his phase of rising-in-power was that everybody is a potential entrepreneur (Bickerton \& Accetti, 2014) and that the same passion and requisites that make a good entrepreneur may make a good political leader. Such rhetoric allowed him to abandon the sophisticated political language of the First Republic, using a more pragmatic and somehow vulgar language. The name of the party recalled the chant of supporters of the national soccer team, which meant to appeal holistically to the entire nation (Ragazzoni, in press). He emphasized that Italians are good just as they are, and stated that politicians were responsible for all the problems of Italian society (Orsina, 2013). In his addresses, he offered hope and other positive words (miracle, trust, dream, happiness) and statements like "the victory of love over hate and envy" or that his party is the "party of love" (Berlusconi, as cited in Körösényi \& Patkos, 2017, p. 616).

The leadership of Berlusconi never fitted the technocratic populism ideal-type completely. For example, he never implemented direct demobilization strategies aiming at instilling civic apathy. However, most of his distinctive features resembled, during the rising-in-power phase, such a theoretical scheme. The strong message against the party government model and the emphasis on his role as a social and professional leader, more than as a party leader, support this claim. The direct appeal to the Italian people-another fundamental element of his narrative-was the main indicator of the distance he took from the old 'partitocrazia' (Bickerton \& Accetti, 2014). The same direct appeal explained his extraordinary peaks of personal consensus at the time of his 1994 victory and even during the first year of his government in 2001 (Bellucci, 2006).

Most of these elements have been recurrent during Berlusconi's long political career. However, after consolidating the leadership of the center-right camp, Berlusconi and his party went through a process of adaptation and 'normalization,' which led to a partial departure from the technocratic populism model. First, despite remaining a personal party incapable of full institutionalization due to Berlusconi's charismatic leadership, Forza Italia went through a process of consolidation with the entering of relevant cadres from Socialist and Christian democratic traditions. Moreover, its legitimation was boosted by Forza Italia's acceptance into the European People's Party in 1998. Second, Berlusconi's 
anti-political and anti-establishment stances were better specified: Instead of overcoming the left-right cleavage, he stressed its significance consolidating his position as the leader of the center-right coalition, and orienting his anti-elite appeal against the post-communist left. Thus, anti-communism became the ideological glue of the new coalition (Ruzza \& Fella, 2011). Berlusconi repeatedly utilized such an argument to demonize not only the postcommunist parties but also relevant functional elites (e.g., judiciary or media; Ragazzoni, in press; Verbeek \& Zaslove, 2016). A significant consequence of this process of 'normalization' was the reduction of Berlusconi's challenge to the party government model. Forza Italia thus became a mainstream 'anti-populist' party opposing the argument of the 5SM and, to some extent, of other radical parties of the centre-right coalition.

Third, the adoption of technocratic expertise as a significant criterion of ministers' selection remained somehow present, but it never became crucial in Berlusconi's practice of government (Table 2). He actually selected a few technocratic ministers (none in his last executive), but not a higher percentage than those appointed by center-left governments in the same period (Verzichelli \& Cotta, 2018). Moreover, some of Berlusconi's technocratic ministers were fired or forced to resign more often than the 'purely political' ministers (Verzichelli, 2009).

Other reflections bring us to define the adaptive nature of Berlusconi's approach to technocratic populism during his long staying-in-power. On the one hand, after the end of his first government and the 1996 electoral defeat, Berlusconi introduced precise references to the republican history (e.g., the role of De Gasperi, the centrality of the European people party, the role of European Integration). These references boosted his legitimation both at the national and international levels, and prepared his political revenge: the great victory of 2001, the 'contract with Italians' and his return to government. On the other hand, the anti-political rhetoric kept being a character of his leadership even after the 2001 election, when Berlusconi dissipated lots of governing energies in his fight with media and judges (Bickerton \& Accetti, 2014). Several episodes can be recalled in this respect; for instance, the 'Bulgarian Edict': An interview given during a visit to Sofia when, in fact, the leader asked the removal of three 'unwelcome' programs from public television. Or even the frequent announcements of a reform of the judiciary (completed in 2004) were presented as a crucial action to "get back judges on the track." All these episodes were patent elements of the resiliency of the original style. One can say that the features of the 'caiman'-technocratic populist symbology and a 'vocal' style of permanent campaigner-alternated to a modest action as policy innovator, which never revolutionized the machinery of the state, the government and most of the policy domains. This explains why the experience in government of Berlusconi remained, in fact, within the frameworks of standard politics (Pasquino, 2012).

\section{Competitors but Disciples: Three Deviations from Berlusconi's Technocratic Populism}

Berlusconi's experience left a clear mark on Italian politics, which may have influenced the strategies of other leaders. We argue that the erratic transformation of Italian politics did not follow the peculiar technocratic populism model traced by Berlusconi, while remaining somehow influenced by that. This assertion can be supported by evaluating three different types of leadership emerged during the 2010s: Mario Monti, Matteo Renzi and Matteo Salvini. They may have relied on some aspects of the technocratic populism model. For instance, the self-made man nature of the leader, his policy expertise, the anti-establishment appeal, the hierarchical conception of the personal party.

\subsection{Mario Monti: The 'Technocratic Opponent'}

Appointed as prime minister in 2011 to deal with the consequences of the economic crisis, after a phase of turmoil for Berlusconi IV government (Pasquino \& Valbruzzi, 2012), Monti formed an apolitical executive (100\% of non-partisan ministers; Culpepper, 2014) and almost fully technocratic government (88.9\% of expert ministers; Verzichelli \& Cotta, 2018). A former European commissioner for competition and president of Bocconi University, Monti was a perfect technocrat, but surely not a technocratic populist. In some sense, he tried to take the opposite direction of Berlusconi's trajectory, when he decided to lead a political cartel in 2013. During the electoral campaign, he launched clear populist messages. In particular, he tried to emulate Berlusconi in circulating the ideas of a skill-based leadership and of a selfmade man. Just to give a colorful example, as the leader of Forza Italia involved his pet dog during the campaign Monti adopted one too. He promised radical and substancial changes moving from a position of centrist and 'mainstream' institutional office-holder, but also focusing on pure populist messages as 'iron hand' against rich people evading taxes. He finally tried (in vain) to be less 'academic' and more 'ordinary people-like.' In the end, Monti's cartel reached less than $10 \%$ of the votes in the election that consecrated the populist 5SM. This electoral defeat also represented the end of Monti's party, which imploded after a few months.

This example resembles the experience of Jan Fischer, who led a popular technocratic government in Czech Republic between 2009 and 2010, running as an independent candidate in the next 2013 presidential elections (Buštíková \& Guasti, 2019). Both cases highlight the differences between a succesfull technocrat and a technocratic populist: There are few chances to transform a remarkable personal popularity based on technocratic credentials, if that candidate is unable to run a populist campaign. Especially when other influential populist competitors emerge. A similar story is represented by another Italian technocratic prime minister: 
Lamberto Dini (former higher officer of the Bank of Italy) who was appointed as a prime minister in 1995. Successively, he started a little centrist party that joined the centre-left coalition, producing a very modest political impact. In the end, the more influential Italian technocratic prime minister was Carlo Azelio Ciampi. A former Governor of the Central Bank appointed prime minister in 1993 in the middle of the Tangentopoli storm, Ciampi became minister of the treasury during the crucial phase of the Euro takeover, and (in 1999) President of the Republic. This without assuming any formal party affiliation and being always out of the daily political debate. Therefore, the 'pure technocrat' Ciampi seems to have had a much longer and stable political influence than ambitious 'technocrats in politics' like Dini and Monti.

\subsection{Matteo Renzi: A True Heir in the Other Camp?}

Among the narratives here analyzed, that of Renzi is the closest to the first image Berlusconi's leadership. After all, many have identified the former prime minister and Democratic Party leader as the true heir of Berlusconi, though expressed by the opposing political camp. However, the commonalities between these two leaderships are mostly related to the classical features of populism, rather than technocratic populism.

The rise of Renzi's leadership occurred during a critical juncture, thanks to his feature of (party) outsider and to a certain anti-establishment appeal. Renzi was already a young career politician and the mayor of Florence, but his approach shares some essential elements with the first Berlusconi technocratic populism model. Indeed, after the unexpected affirmation in the primary elections contest for the city of Florence (2008) and the good result in his first attempt at the 2010 Democratic Party national secretary election (marked by the slogan "let's scrap old politicians"), he got the party leadership in 2013. Then, he became prime minister in 2014 (Bordignon, 2014).

Renzi's anti-establishment appeal is peculiar. Although he had a clear party connotation, like Berlusconi he addressed a sharp criticism to the party elite, and particularly to the post-communist party oligarchy. Renzi's political project was connected to the concept of scrapping (rottamazione), which meant the demotion of the whole party's establishment (Bordignon, 2014). An 'us versus them' characterized his rhetoric, where party oligarchies represented the 'them' while the ordinary people constituted the 'us.' Thanks to this rhetoric, Renzi projected an image of an outsider and self-made leader just as Berlusconi did in 1994. In doing so, he obtained an even higher rate of personal consensus as a chief executive. According to the pollster Demos \& Pi (n.d.), the popularity of Renzi as leader reached the astonishing level of 74\% in June 2014, 4 months after the formation of his government, while the decline started in January 2015.

During Renzi's staying-in-power, the 'us versus them' divide was expanded, going beyond the boundaries of the party and criticizing the economic and financial power (e.g., banks). Moreover, he attacked the traditional cultural establishment of the left party, dominated by trade unions and bureaucrats. The idea was to elaborate a postideological political proposal and a catch-all electoral strategy focused on concepts as innovation, rapidity, and education to appeal to all Italians beyond the classical left-right divide, as Berlusconi did in 1994 (Bordignon, 2014). The style of communication was the dimension in which Renzi was more 'inspired' by Berlusconi. Both of them used simple and popular language, abandoning the formal code of politics, with the same aim of establishing a direct and emotional connection with ordinary people (Bickerton \& Accetti, 2014). Renzi, in particular, focused on young people, making frequent references to Matt Groening's The Simpsons or Mary Poppins. His language was simple and made up of slogans and catchphrases, with a rhetorical use of 'stories' of ordinary citizens. Just as Berlusconi, Renzi used the language of hope and love. He affirmed, for example, that mayors write love letters to their cities everyday (Bordignon, 2014).

As said, these similarities relate to classical features of populism. The same cannot be said about the technocratic side of technocratic populism. Contrary to Berlusconi, Renzi never exploited the idea of running the state as a firm, despite several elements stress the presence of some kind of technocracy. In particular, we can mention the following: On the one hand, the plebiscitary approach with the invocation of direct democracy and the attacks on the role of parties; on the other hand, his idea of dirigisme, with a set of policy proposals defined in advance, and thus no longer in need of public debate or justification (Bickerton \& Accetti, 2014). Moreover, in his government, he selected a higher percentage of technocratic and non-partisan ministers if compared with Berlusconi (Table 2).

Another difference between Renzi and Berlusconi concerns their anti-elite approach. While the latter used the classical antithetical categories of 'elite' and (hardworking) 'people,' the former introduced a generational divide. However, just as Berlusconi did with the category of 'entrepreneur,' Renzi offered an idea of generational change as a condition of a new spirit of progress (Bickerton \& Accetti, 2014). The relationship with their respective parties was another difference between Berlusconi and Renzi. The latter attempted to de-institutionalize his party, aiming at transforming the Democratic Party in a light, open, and leader-centered party (Bordignon, 2014). However, he never reached the full control exerted by the former on Forza Italia until he founded his own small (but personal) party, Italy Alive (Italia Viva) in 2019.

\subsection{Matteo Salvini: The Nativist Heir of Berlusconi}

Matteo Salvini is the successor of Berlusconi as centerright coalition leader. Journalistic and academic analyses often stress the line of continuity between the old 
tycoon and the new sovereignist leader, focusing on their strong sense of party personalization, as well as their media omnipresence.

Between his election as Lega Nord's leader in 2013 and his political consecration-the 2018 election when the League for Salvini Premier (a new party name marking a clear personalist and nationalistic drift) became the largest party of the center-right coalition-Salvini imposed a significant change both to the strategy and the discourse of his party. Besides the abandonment of the traditional federal issue, he flirted with fascist groups and oriented the party toward some of the classical radical right issues. For instance, anti-immigration and antiglobalization claims (Caiani, 2019; Pucciarelli, 2016).

A closer look to his political trajectory confirms that Salvini has somehow shared a few features of Berlusconi's technocratic populism. As the 'maestro,' he developed his leadership during a critical juncture of party scandals and consolidated it thanks to the adversarial mode taken by the party against the previous 'proEuropeanist elites' after the economic crisis 2008-2013. As Berlusconi, he claimed to be an outsider: despite the fact that he had always been a professional politician, Salvini had no previous party/governmental roles. His anti-elite approach was often oriented against the 'left establishment' and against the national and supranational 'strong powers.' Moreover, he developed an assertive style of communication, based on vulgar language and direct connection with the people. In this regard, Salvini even surpassed Berlusconi, adopting a form of mobilization that resembles the pure populist style. Indeed, he boosted a state of permanent electoral campaign, as Trump did in the USA.

It is worth to pause when the problem of 'stayingin-power' comes, to distinguish the purely (right) populist drift of Salvini. Differently from Berlusconi, the personalization of the Northern League did not follow a 'franchising strategy' and did not reach the same level of Forza Italia, although he was more successful than, for example, Renzi in de-institutionalizing his own party. Moreover, ideologically he joined the new European (and international) radical right adopting a nativist perspective (no migrants, Italians first) and a deep antiEuropeanist stance (Albertazzi, Giovannini, \& Seddone, 2018). These rhetoric images became, after the 2018 elections, more relevant than the classical people versus élites divide. Moreover, instead of focusing on technocratic management of the state, Salvini impressed a pure political meaning to his participation in the first Conte government. Indeed, he was the most vocal political guide, and he tried to balance the non-partisan nature of the Prime minister with a broad action on different fields of the whole governmental agenda. In doing so, he marked a relevant difference in comparison to the other vice-premier: the 5SM leader Luigi Di Maio (Marangoni \& Verzichelli, 2019). The critical targets of Salvini's rhetoric were, in particular, multiculturalism, the politics of retrenchment, and the subordination to the European technocracy. Thanks to the continuous use of these issues, Salvini built his role as a purely rightnativist populist leader.

\section{Conclusion: Technocratic Populism Legacies in Italy and the Outbreak Crisis}

As we stressed in the introduction, although emerged only during the rising phase of Berlusconi, technocratic populism had evident roots in Italy, due to an ancestral populist mentality and a recurrent demand for 'real skills,' technocratic actions, and limitations of party government. Writing two (complicate) years after the beginning of the XVIII legislative term, marked by the entrance in the government of a purely populist party like 5SM, which was the strongest party to support both governments formed by Giuseppe Conte in 2018 and 2019, we may hypothesize that some of these elements are still latent and they may come back, although taking different routes. The uncertainties of this troublesome period and the 2020 pandemic outbreak may represent a new critical juncture to be governed by changeable and adaptive political narratives. This may lead, in turn, to the rise of a new peculiar form of technocratic populism.

The persisting debate on pros and cons of party government is the first element we can recall to support our impressionistic assertion. The Conte II government was formed in 2019 to reach a new political equilibrium concerning the Italy-EU relationship and in several other policy fields. Conte, a non-partisan figure initially recruited by the $5 \mathrm{SM}$ as a potential candidate for the role of minister of public administration reforms, had been promoted to the office of chief executive in 2018, having the two leaders of the populist coalition (Salvini and Di Maio) as vice-prime ministers. After the breakdown of the populist alliance with the League, 5SM joined its forces with the Democratic Party, Liberi and Uguali and the small personal party recently formed by Renzi. To some extent, this can be seen as the return to a more 'familiar' partygovernment coalition. However, the growing personal popularity (more than $70 \%$ in the spring of 2020; see Demos \& Pi, n.d.) and the growing independence of the prime minister, both of them boosted by the pandemic crisis, could allow him to play an increasingly political rather than purely technocratic role. Conte could take the lead of a new type of coalition and play the role of a competent professional 'brought into real politics.' Hence, the resurgence of some technocratic populism traits looks possible during such a complicated situation.

A second intriguing element in the evolution of the leadership of Giuseppe Conte during the outbreak emergency is the notion of political responsibility in the context of a permanent change of political agendas. The direct connection between the government and the scientific community, the timely decisions imposed by the crisis, and the trade-off between safety and support to the economy, may have fostered his political leadership. He can be said 'more competent' than ordi- 
nary politicians, not too connected to ideologies and, above all, foreign to any party machinery. In this circumstance, Conte has therefore played the role of the expert state-manager, assuring his responsiveness by issuing prompt regulatory measures (both during and after the lock-down) and making extensive use of urgent legislative decrees. More importantly, from our perspective, Conte has developed a rather personalized communicative strategy. More precisely, he has directly addressed the public, and sometimes he has exploited some institutional events to attack opposition figures (in particular the sovereignist leaders Salvini and Meloni) openly. But he has sometimes taken distance also from the same political forces of his parliamentary majority. During the outbreak, Conte has been extraordinarily active on media and social networks, illustrating his visions for the prospective re-launch of the country. In doing so, he has offered his role as a political fixer to solve the dilemma between the confinement measures inspired by and defined with the scientific community (technocratic side) and the needs of the countless sectors of the Italian society penalized by the crisis (populist side).

Conte was heavily criticized by almost all the party leaders (both from the majority and the opposition) for the excessive use of decrees and a growing reliance on his technocratic team (extended during the Covid-19 outbreak to a considerable number of 'scientific advisors'). Though justifiable by the critical situation, these behaviors may also be seen as possible signs of an emerging challenge to the parliament and representative democracy. Conte cannot count on the personal resources of Berlusconi or the political resources that Renzi had in 2014. He will probably be forced to risk everything in the game of his leadership transformation, being tempted to adopt a more technocratic populist profile. However, such a fluid situation leaves many options still open.

In sum, what we have learned, applying the category of technocratic populism to 25 years of Italian politics, is that, notwithstanding the relevance of Berlusconi as a trendsetter and an inspiring model of a businessparty leader, Italy was not the land of technocratic populist conquest. Only the short experience of Renzi as party (and governmental) leader can be, to some extent, associated with this ideal-type. However, after discovering the applicability of a mix between elements of populist mentality and features of technocratic government, Italians are still exposed to such a temptation. Conte, certainly not a populist party leader and a weak technocratic chief executive at the beginning of his political experience in 2018, has become a completely different figure. He may be somehow associated with the return of some elements of technocratic populism, especially in the aftermath of the 2020 outbreak.

In other words, if all the political narratives we have shortly reported above can be compared to the technocratic populism model inspired and interpreted by Berlusconi at the beginning of his political trajectory, all of them had to rearrange the same model in a rather rad- ical way. Conte seems to have built his political leadership from a completely different perspective. But he also presents an interesting adaptive approach, which may lead him to rediscover the advantages of technocratic populism and offer the Italian democracy a new possible future leadership.

\section{Acknowledgments}

The authors thank the Academic Editors of the thematic issue and the anonymous reviewers for their valuable comments.

\section{Conflict of Interests}

The authors declare no conflict of interests.

\section{References}

Abt, K., \& Rummens, S. (2007). Populism versus democracy. Political Studies, 55(2), 405-424.

Albertazzi, D., Giovannini, A., \& Seddone, A. (2018). 'No regionalism please, we are Leghisti!': The transformation of the Italian Lega Nord under the leadership of Matteo Salvini. Regional \& Federal Studies, 28(5), 645-671.

Barr, R. R. (2009). Populists, outsiders and antiestablishment politics. Party Politics, 15(1), 29-48.

Bellucci, P. (2006). All'origine della popolarità del governo in Italia, 1994-2006 [At the origin of the government's popularity in Italy, 1994-2006]. Rivista Italiana di Scienza Politica, 36(3), 479-504.

Berlusconi, S. (2000). L'Italia che ho in mente [The Italy that I have in mind]. Milan: Mondadori.

Bickerton, C. J., \& Accetti, C. I. (2014). Democracy without parties? Italy after Berlusconi. The Political Quarterly, 85(1), 23-28.

Bickerton, C. J., \& Accetti, C. I. (2017). Populism and technocracy: Opposites or complements? Critical Review of International Social and Political Philosophy, 20(2), 186-206.

Bordignon, F. (2014). Matteo Renzi: A 'leftist Berlusconi' for the Italian democratic party? South European Society and Politics, 19(1), 1-23.

Buštíková, L., \& Guasti, P. (2019). The state as a firm: Understanding the autocratic roots of technocratic populism. East European Politics and Societies and Cultures, 33(2), 302-330.

Caiani, M. (2019). The populist parties and their electoral success: Different causes behind different populisms? The case of the Five-star Movement and the League. Contemporary Italian Politics, 11(3), 236-250.

Canovan, M. (1984). 'People,' politicians and populism. Government and Opposition, 19(3), 312-27.

Caramani, D. (2017). 'Will vs. reason': The populist and technocratic forms of political representation and their critique to party government. American Political Science Review, 111(1), 54-67. 
Castaldo, A. (2018). Populism and competitive authoritarianism in Turkey. Southeast European and Black Sea Studies, 18(4), 467-487.

CIRCaP. (n.d.). Italian political elite [Data set]. Retrieved from www.circap.org

Corduwener, P. (2017). Challenging parties and antifascism in the name of democracy: The fronte dell' uomo qualunque and its impact on Italy's Republic. Contemporary European History, 26(1), 69-84.

Cotta, M., \& Verzichelli, L. (1996). Italy: The sunset of a partycracy. In J. Blondel \& M. Cotta (Eds.), Party and government: An inquiry into the relationship between governments and supporting parties in liberal democracies (pp. 180-201). London: Palgrave Macmillan.

Culpepper, P. D. (2014). The political economy of unmediated democracy: Italian austerity under Mario Monti. West European Politics, 37(6), 1264-1281.

Demos \& Pi. (n.d.). Atlante politico n. 88 - Giugno 2020 [Political atlas No. 88-June 2020]. Demos \& Pi. Retrieved from http://www.demos.it/a01738.php

Eatwell, R., \& Goodwin, M. (2018). National populism: The revolt against liberal democracy. London: Penguin.

Fella, S., \& Ruzza, C. (2013). Populism and the fall of the centre-right in Italy: The end of the Berlusconi model or a new beginning? Journal of Contemporary European Studies, 21(1), 38-52.

Foot, J. (2014). Modern Italy. Basingstoke: Palgrave Macmillan.

Havlík, V. (2019). Technocratic populism and political illiberalism in central Europe. Problems of PostCommunism, 66(6), 369-384.

Hawkins, K. A., Carlin, R. E., Littvay, L., \& Rovira Kaltwasser, C. (Eds.). (2019). The ideational approach to populism: Concept, theory and analysis. Abingdon: Routledge.

Jagers, J., \& Walgrave, S. (2007). Populism as political communication style: An empirical study of political parties' discourse in Belgium. European Journal of Political Research, 46(3), 319-345.

Katz, R. (1987). Party government and its alternatives. In R. Katz (Ed.), Party governments: European and American alternatives (pp. 1-26). Berlin: Walter de Gruyter.

Körösényi, A., \& Patkos, V. (2017). Variations for inspirational leadership: The incumbency of Berlusconi and Orban. Parliamentary Affairs, 70(3), 611-632.

Mair, P. (2002). Populist democracy vs. party democracy. In Y. Mény \& Y. Surel (Eds.), Democracies and the populist challenge (pp. 81-98). London: Palgrave Macmillan.

Marangoni, F., \& Verzichelli, L. (2019). Goat-stag, chimera or chameleon? The formation and first semester of the Conte government. Contemporary Italian Politics, 11(3), 263-279.

Moffitt, B. (2016). The global rise of populism: Performance, political style, and representation. Stanford, CA: Stanford University Press.
Mudde, C. (2004). The populist zeitgeist. Government and Opposition, 39(4), 541-563.

Mudde, C., \& Kaltwasser, C. R. (2013). Exclusionary vs. inclusionary populism: Comparing the contemporary Europe and Latin America. Government and Opposition, 48(2), 147-174.

Orsina, G. (2013). I/ berlusconismo nella storia dell'Italia [Berlusconism in Italian history]. Venice: Marsilio.

Paolucci, C. (2008). From Democrazia Cristiana to Forza Italia and the Popolo della Libertà: Partisan change in Italy. Modern Italy, 13(4), 465-480.

Pappas, T. S. (2019). Populism and liberal democracy: $A$ comparative and theoretical analysis. Oxford: Oxford University Press.

Pasquino, G. (2007). The five faces of Silvio Berlusconi: The knight of antipolitics. Modern Italy, 1(12), 39-54.

Pasquino, G. (2012). Italy: Goodness, badness, and the trajectories of mediocrity. In L. Helms (Ed.), Poor leadership and bad governance: Reassessing presidents and prime ministers in North America, Europe and Japan (pp. 130-148). Cheltenham and Northampton: Edward Elgar Publishing.

Pasquino, G., \& Valbruzzi, M. (2012). Non-partisan governments Italian-style: Decision-making and accountability. Journal of Modern Italian Studies, 17(5), 612-629.

Pucciarelli, M. (2016). Anatomia di un populista: La vera storia di Matteo Salvini [Anathomy of a populist: The true story of Matteo Salvini]. Milan: Feltrinelli.

Ragazzoni, D. (in press). The populist leader's two bodies: Bobbio, Berlusconi, and the factionalization of party democracy. Constellations: An International Journal of Critical and Democratic Theory.

Rovira Kaltwasser, C., Taggart, P., Ochoa Espejo, P., \& Ostiguy, P. (Eds.). (2017). The Oxford handbook of populism. Oxford: Oxford University Press.

Ruzza, C., \& Fella, S. (2011). Populism and the Italian right. Acta Politica, 46(2), 158-179.

Taggart, P. (2000). Populism. Buckingham: Open University Press.

Tarchi, M. (2008). Italy: A country of many populisms. In D. Albertazzi \& D. Mcdonnell (Eds.), Twentyfirst century populism: The spectre of western European democracy (pp. 84-99). Basingstoke: Palgrave Macmillan.

Tarchi, M. (2015). Italy: The promised land of populism? Contemporary Italian Politics, 7(3), 273-285.

Verbeek, B., \& Zaslove, A. (2016). Italy: A case of mutating populism? Democratization, 23(2), 304-323.

Verzichelli, L. (1998). The parliamentary elite in transition. European Journal of Political Research, 34(1), 123-151.

Verzichelli, L. (2009). Italy: The difficult road towards a more effective process of ministerial selection. In $\mathrm{K}$. Dowding \& P. Dumont (Eds.), The selection of ministers in Europe: Hiring and firing (pp. 89-100). London: Routledge.

Verzichelli, L., \& Cotta, M. (2018). Shades of technocra- 
cy: The variable use of non-partisan ministers in Italy. In A. Costa Pinto, M. Cotta, \& P. Tavares de Almeida (Eds.), Technocratic ministers and political leadership in European democracies (pp. 77-110). London: Palgrave.

Zaslove, A. (2008). Here to stay? Populism as a new party type. European Review, 16(3), 319-336.

Zulianello, M. (2020). Varieties of populist parties and party systems in Europe: From state-of-the-art to applying a novel classification scheme to 66 parties in 33 countries. Government and Opposition, 55(2), 327-347.

\section{About the Authors}

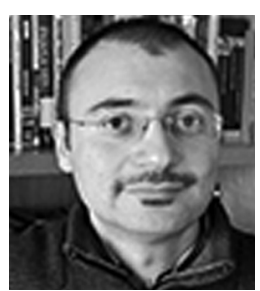

Antonino Castaldo is Postdoctoral Research Fellow at the Instituto de Ciências Sociais, Universidade de Lisboa, Av. Professor Aníbal de Bettencourt 9, 1600-189 Lisboa, Portugal. He has a PhD in Political Science from the University of Florence. He was Teaching and/or Research Assistant at the University of Science Po (Paris), University of Roma Tre, Luiss University, and University of Oxford. He is currently working on populism and autocratization processes, with specific reference to the diffusion of competitive authoritarian regimes, and a focus on the Balkan region and the Middle East.

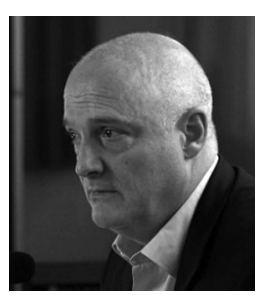

Luca Verzichelli is Professor of Political Science at the University of Siena, where he teaches Italian Politics and Global Comparative Politics. He holds a PhD in Political Science from the University of Florence. He has been Visiting Scholar at the Universities of Granada, Jena, Oxford, Montréal and at the Australian National University. He has extensively published in the fields of comparative political institutions and political elites in Europe. 